\title{
Antioxidant activity of timolol on endothelial cells and its relevance for glaucoma course
}

A Izzotti ${ }^{1}$, SC Saccà², B Di Marco'1, S Penco ${ }^{3}$ and AM Bassi ${ }^{3}$

\begin{abstract}
Purpose A growing evidence in the scientific literature suggests that oxidative damage plays a pathogenic role in primary open-angle glaucoma. Therefore, it is of interest to test whether drugs effective against glaucoma display antioxidant activity. We test the hypothesis that the classic $\beta$-blocker therapy for glaucoma with timolol involves the activation of antioxidant protective mechanisms towards endothelial cells.

Methods Oxidative stress was induced in cultured human endothelial cells by iron/ ascorbate with or without timolol pretreatment. Analysed parameters included cell viability (neutral red uptake and tetrazolium salt tests), lipid peroxidation (thiobarbituric reactive substances), and occurrence of molecular oxidative damage to DNA (8-hydroxy-2'-deoxyguanosine).

Results Oxidative stress decreased 1.8-fold cell viability, increased 3.0-fold lipid peroxidation and 64-fold oxidative damage to DNA. In the presence of timolol, oxidative stress did not modify cell viability, whereas lipid peroxidation was increased 1.3-fold, and DNA oxidative damage 3.6 -fold only. Conclusions The obtained results indicate that timolol exerts a direct antioxidant activity protecting human endothelial cells from oxidative stress. These cells employ mechanisms similar to those observed in the vascular endothelium. It is hypothesized that this antioxidant activity is involved in the therapeutic effect of this drug against glaucoma.

Eye (2008) 22, 445-453; doi:10.1038/sj.eye.6702737; published online 9 February 2007
\end{abstract}

Keywords: oxidative stress; DNA damage; endothelial cells; timolol; antioxidant; glaucoma

\section{Introduction}

Although during glaucoma course, a low intraocular pressure (IOP) does not contribute to the progression of visual field damage, IOP increase alone does not justify all the noticeable alterations affecting the retinal ganglion cells in glaucoma. ${ }^{1-3}$ It has been suggested that mechanical and vascular factors, through the induction of oxidative damage, lead to the same final pathologic consequence by working synergistically. ${ }^{4}$ The increase in oxidative DNA damage in the cellular component of the trabecular meshwork affects the architecture of the extracellular matrix and the related IOP regulation, leading to the clinical onset of glaucoma., ${ }^{5,}$ On the basis of these premises, the anterior chamber of the eye can be regarded as a highly specialized vascular compartment whose inner walls are composed of the endothelia of iris, cornea, and trabecular meshwork. ${ }^{7}$ From a physio-pathological point of view, the endothelial cells play an essential role in the anterior chamber(AC) of the eye, as they do in blood vessels.

Anterior chamber endothelial cells are constantly in contact with free radicals, and are endowed with antioxidant activities which counteract the toxic effects of oxidative stress. $\mathrm{H}_{2} \mathrm{O}_{2}$ may damage endothelial cells through direct oxidation of lipids, proteins, and DNA or it can act as a signal vs molecule to trigger intracellular pathways, leading to cell death. It has been demonstrated that in glaucomatous $\mathrm{AC}$ there is a $57 \%$ increase in super oxide dismutase(SOD) activity as compared with unaffected controls. ${ }^{8}$ Moreover, AC endothelial cells express the endothelial leukocyte adhesion molecule-1 (ELAM-1), the earliest marker of atherosclerotic plaque in the vasculature. ELAM-1 is consistently present in trabecular meshwork (TM) cells in the outflow pathways of eyes bearing glaucoma. ${ }^{9}$
${ }^{1}$ Department of Health Sciences, University of Genoa, Italy

${ }^{2}$ Department of Head/Neck Pathologies, St Martino Hospital: Ophthalmology Unit, Genoa

${ }^{3}$ Department of Experimental Medicine, University of Genoa, Italy

Correspondence: SC Saccà, St Martino Hospital: Ophthalmology Unit, Largo Rosanna Benzi 1, Pad Spec. 4 piano. 16132 Genoa, Italy Tel: + 39-010 555 2443; Fax: + 39-010 5556585 . E-mail: sergio.sacca@ hsanmartino.it

Received: 9 August 2006 Accepted in revised form: 27 December 2006 Published online: 9 February 2007 
Much evidence indicates that trabecular endothelial cells play a fundamental role in the outflow of aqueous humour from the anterior chamber to the Schlemm's canal. ${ }^{10}$ Trabecular meshwork pores contribute only $10 \%$ of the aqueous outflow resistance. ${ }^{11}$

On the whole, these data indicate that the outflow of aqueous humor is probably regulated through an active mechanism. ${ }^{12}$ Thus, the tri-dimensional architecture of human trabecular meshwork (HTM) considerably increases the filtration surface, whose degeneration, resulting in the decay of HTM cellularity, causes IOP increase and triggers glaucoma pathogenesis. ${ }^{13}$

Cellular senescence may also contribute to the increase in aqueous humor outflow resistance and IOP increase commonly associated with primary open-angle glaucoma (POAG).$^{14}$ The accumulation of senescent cells has been proposed to contribute to the loss of tissue function during aging, ${ }^{15}$ the constant exposure of TM cells to an oxidative environment potentially contributing to premature cellular senescence. ${ }^{16}$ Several lines of evidence support the view that glaucomatous damage is the pathological consequence of oxidative stress, especially when the first line of antioxidant defense weakens with age. ${ }^{17}$ Oxidative damage could also explain the vascular damage associated with glaucoma. ${ }^{18}$ In any case, it is well established that oxidative stress is associated with arterial blood pressure increase, which may cause endothelial dysfunction and altered vascular reactivity. ${ }^{19}$

According to this view, it is conceivable that a drug able to decrease IOP could also have a protective action on endothelial cells.

In this paper, we explore the possibility that $\beta$-blocker therapy of glaucoma with timolol could exert a protective antioxidant action on endothelial cells. We focus our attention on endothelial cells, and hypothesize that endothelial cells belonging to the different tissues of the whole anterior chamber (trabecular meshwork, iris, cornea), which is akin to a vascular compartment, play a fundamental role as a first line of interaction with the aqueous humour. Accordingly, we used a wellstandardized endothelial cell line (HECV), which is commonly used to evaluate the toxic effects of reactive oxygen species, to test the antioxidant activities of timolol.

\section{Methods}

\section{Chemicals}

Standard culture medium, foetal bovine serum, and supplemented compounds were purchased from Sigma Chemical Co. (St Louis, MO, USA). All other chemicals and solvents were of analytical grade and were from common commercial sources. Cell culture flasks and plates were obtained from Costar (Cambridge, MA, USA).

\section{Cell culture conditions}

The endothelial cell line HECV, provided by Cell Bank and Culture in GMP (IST -Genoa, Italy), was maintained at $37^{\circ} \mathrm{C}$ in a humidified atmosphere with $5 \% \mathrm{CO}_{2}$ as monolayers in Dulbecco's modified Eagle's medium supplemented with $7 \%(\mathrm{v} / \mathrm{v})$ heat-inactivated foetal bovine serum and $2 \mathrm{~mm} \mathrm{L-glutamine.} \mathrm{The} \mathrm{medium} \mathrm{was}$ changed every 2 days, and when the original flask was approximately $80 \%$ confluent, the cells were subcultured in the $1: 4$ ratio by mechanical scraping. All cell cultures were proved to be mycoplasma-free using the DNA fluorochrome staining method with bis-benzymide dye (Hoechst 33258). All the cultures were morphologically checked each day. Total cell number was evaluated by hemocytometer.

\section{Cell treatments}

HECV cells were seeded in 24-well plates at $10^{5}$ cells/ well, to reach semiconfluence ( $80 \%$ ) after $48 \mathrm{~h}$. Solution of $\mathrm{FeSO}_{4} /$ ascorbic acid (Fe/Asc), solved in complete medium and water respectively, was added to the medium to achieve the final concentrations of $0.2 \mathrm{~mm}$ $\left(\mathrm{FeSO}_{4}\right)$ and $1 \mathrm{~mm}$ (ascorbic acid). Twelve hours after seeding four plates, HECV cells were washed with warm phosphate buffer saline (PBS) to remove detached cells and catabolites. Then, one plate was untreated (control); one was treated for $24 \mathrm{~h}$ with timolol only $(0.5 \mathrm{mg} / \mathrm{ml}$ complete medium/well) (timolol); one was exposed to the pro-oxidant mixture ( $\mathrm{Fe} / \mathrm{Asc}$ ) for the last $4 \mathrm{~h}$ of culture; one, after pre-treatment with timolol for $20 \mathrm{~h}$, was exposed for $4 \mathrm{~h}$ to the pro-oxidant system (timolol $+\mathrm{Fe} / \mathrm{Asc}$ )

\section{Cell viability assessment}

Cell viability was tested before and after each treatment by means of two tests: neutral red uptake (NRU) and tetrazolium salt test (MTT), which respectively assess the uptake of a hydrophilic dye (neutral red, NR) in the lysosome machinery and the activity of the mitochondrial respiratory chain. At each check point time, experimental medium was removed and cell cultures were washed twice with PBS, then the fresh medium containing neutral red or tetrazolium salt was added. The NRU cytotoxicity assay is a cell survival/ viability chemosensitivity assay, based on the ability of viable cells to incorporate and bind neutral red, a 
supravital dye. NR is a weak cationic dye that readily penetrates cell membranes by non ionic diffusion, accumulating in lysosomes, where it binds to the anionic sites of the lysosomal matrix. Cellular alterations resulting in lysosomal fragility cause a decreased uptake of NR. Cell monolayers were exposed to a neutral red dye-containing medium $(50 \mu \mathrm{g} / \mathrm{ml})$ and processed according to the method of Borenfreund and Puerner. ${ }^{20}$ After incubation for $3 \mathrm{~h}$ at $37^{\circ} \mathrm{C}$, cells were washed twice in PBS and fixed according to the procedure described by Riddel et $a^{21}$ After $10 \mathrm{~min}$ at room temperature, the absorbance of extracted neutral red dye was read at $540 \mathrm{~nm}$ in a Uniskan II microplate reader (Lab-Systems, Helsinki, Finland).

The principle of evaluating cell viability by the MTT cytotoxicity assay is the conversion of the tetrazolium salt (MTT) to the coloured product formazan by viable cells, as occurring in mitochondria. Cells were exposed for $3 \mathrm{~h}$ to a tetrazolium salt-containing medium $(500 \mu \mathrm{g} / \mathrm{ml})$ as described by Mosmann. ${ }^{22}$ Formazan dark-blue crystals were dissolved by adding $1 \mathrm{~N}$ hydrogen

chloride:Isopropanol $(1: 24, \mathrm{v} / \mathrm{v})$. The plates were left at room temperature for $10 \mathrm{~min}$ and the absorbance measured spectrophotometrically at $550 \mathrm{~nm}$.

\section{Determination of thiobarbituric acid-reactive substances}

The determination of thiobarbituric acid reactive substances (TBARS) ${ }^{23,24}$ is used as an index of membrane lipid peroxidation. TBARS were measured both in the experimental media and in cell monolayers, according to the spectrofluorometric method of Iguchi et $\mathrm{al}^{25}$ with minor modifications. ${ }^{26,27}$ Following the pro-oxidant stimulus, $0.2 \%$ Triton $\mathrm{X}-100$ was added to the whole cultures (cell monolayers plus medium), after which $1 \mathrm{ml}$ of the lysate was mixed with a solution containing $0.38 \%$ TBA in $15 \%$ trichloroacetic acid, $0.25 \mathrm{~N} \mathrm{HCl}$, and $0.01 \%$ butyl hydroxytoluene. The tubes containing the mixture were then placed in boiling water for $15 \mathrm{~min}$ and cooled at room temperature. To extract TBARS, $n$-butanol was added and the organic phase was separated by centrifugation. TBARS were quantified by spectrophotometry $\left(\lambda_{\text {exc }}=515 \mathrm{~nm} ; \lambda_{\mathrm{em}}=552 \mathrm{~nm}\right)$ using a LS5 Perkin-Elmer spectrofluorometer. The results were expressed in TBARS equivalents, using 1,1,3,3-

tetraethoxypropane as a standard, and referred to the cell number obtained from a parallel control culture.

\section{Evaluation of oxidative damage to DNA}

Oxidative damage to DNA was evaluated by detecting 8-hydroxy-2'-deoxyguanosine (8-oxo-dG), the most abundant oxidized nucleotide detectable in eukaryotic cells. ${ }^{28} 8$-oxo-dG was analysed by trifluoracetic acid enrichment, ${ }^{32} \mathrm{P}$-postlabelling, bidimensional thin layer chromatography, and ${ }^{32} \mathrm{P}$-imaging, as reported previously ${ }^{17,29,30}$ DNA-free samples were used as negative controls. A reference standard of authentic 8-oxo-dG (Midwest Research Institute, National Cancer Institute Chemical Repository, Kansas City, MI USA) was used in each experiment.

\section{Statistical analyses}

Results are expressed as means \pm SEM and means \pm SD of at least three independent experiments performed in triplicate. Significance was assessed by one-way analysis of variance (ANOVA) followed by Dunnet test or by Student's $t$-test.

\section{Results}

\section{Cell viability and lipid peroxidation}

HECV cell cultures were observed by phase-contrast inverted microscopy at the end of treatments (Figure 1). Standard cultures in the logarithmic phase showed a bipolar shape and small cytoplasmic vacuoles (Figure 1a). After $4 \mathrm{~h}$ of exposure to Fe/Asc, morphological evidence of toxic effects was detected (Figure 1b). After $24 \mathrm{~h}$ of exposure to timolol no cytotoxic effects was observed (Figure 1c). No marked alteration of the cellular morphology was observed in case of association of timolol with pro-oxidant stimulus (Figure 1d). Similar consideration can be drawn in quantitative terms as evaluated by NRU test (Table 1).

Lipid peroxidation measured as TBARS was increased 3.0-fold in the presence of the pro-oxidant stimulus (Table 2). Timolol did not significantly influence lipid peroxidation, whereas it was effective in protecting the cells from the pro-oxidant stimulus (Table 2).

\section{Oxidative damage to DNA (8-oxo-dG)}

The presence of 8-oxo-dG was detected in all examined samples as a radioactive spot of variable intensity migrating in the upper part of the chromatographic area (Figure 2). The oxidant treatment dramatically increased 64-fold the basal 8-oxo-dG levels (Table 3, first line; Figure 2, upper-right panel). When administered alone, timolol did not modify the basal 8-oxo-dG amounts as compared to untreated cells $(0.55 \pm 0.12$ vs $0.51 \pm 0.10$, not significant) (Table 3; Figure 2, lower-left panel). Timolol was quite effective in counteracting the oxidative DNA damage induced by Fe/Asc, the 8-oxo-dG increase being decreased from 64- to 3.6-fold only $(32.65 \pm 4.58$ vs $1.96 \pm 0.39, P<0.001$ ) (Table 3; Figure 2, lower-right 

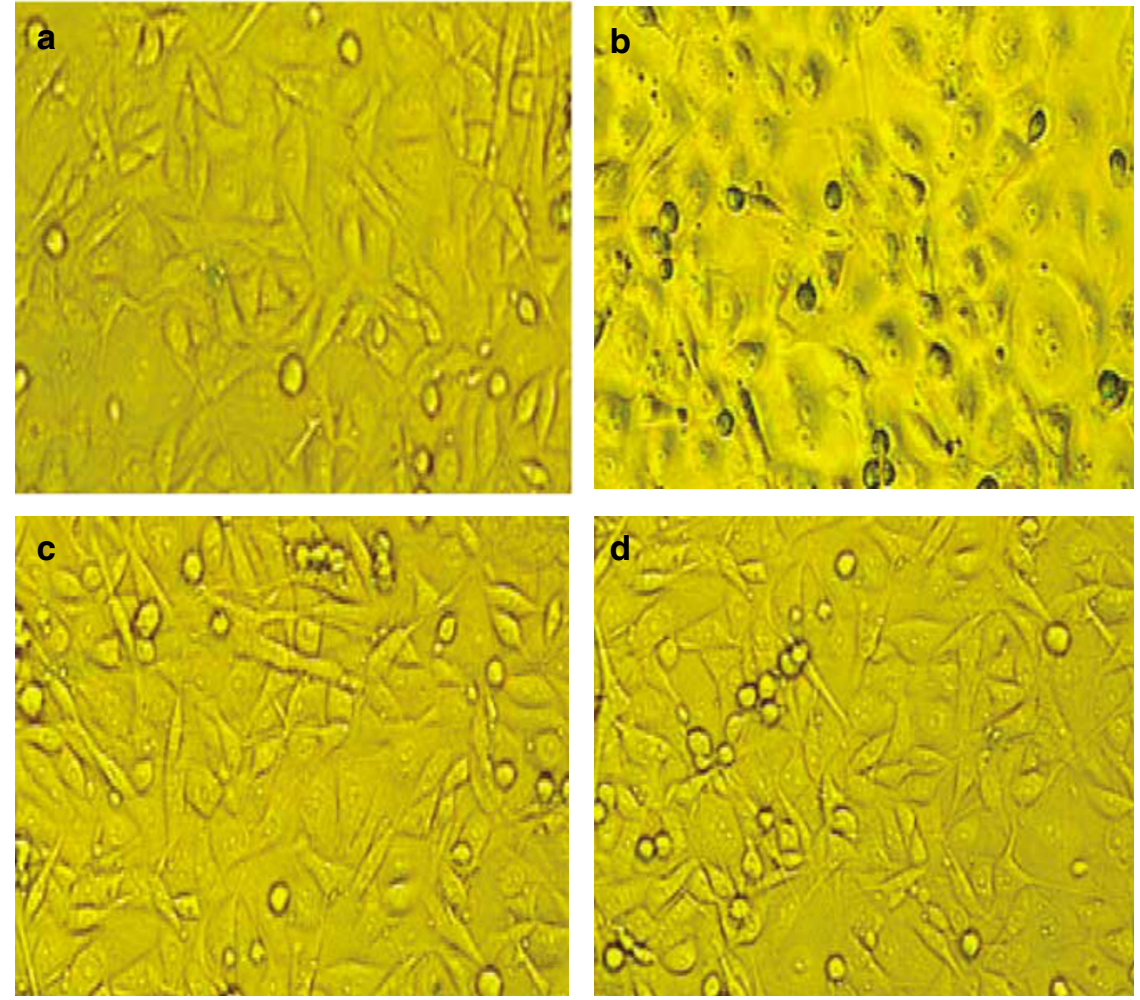

Figure 1 Human endothelial vascular cell line (HECV), as analysed by phase-contrast microscopy $(\times 100)$. (a) Untreated HECV cells (control): the monolayer results in endothelial cells with heterogenous shape (polygonal, spindle, round) refracting the light. Cells reveal a tight anchorage to the plastic support. (b) HECV cells after exposure for $4 \mathrm{~h}$ to Fe/Asc: the monolayer appears erratic; cells are dramatically altered in their morphology being different in size (small, scanty, wrinkled) with marked cytoplasmic inclusions and irregular borders; cells are irregularly grouped, and barely cohesive. (c) HECV cells after $24 \mathrm{~h}$ exposure to timolol: no evidence of altered morphology; border are regular, cells cohesive, and size normal. (d) The association between timolol and Fe/Asc reverses the marked cytotoxicity induced by Fe/Asc, cell morphology being normal.

Table 1 Viability of HECV cells after $24 \mathrm{~h}$ exposure to timolol alone or in association with pro-oxidant stimulus as evaluated by the NRU test

\begin{tabular}{lcc}
\hline Pretreatment & Pro-oxidant & NRU (\% viable cells $)$ \\
\hline None & None & 100 \\
& $\mathrm{FeSO}_{4} /$ ascorbate & $56 \pm 7.4^{*}$ \\
\multirow{2}{*}{ Timolol } & None & $98 \pm 2.1$ \\
& $\mathrm{FeSO}_{4} /$ ascorbate & $97 \pm 2.4^{\circ}$
\end{tabular}

Abbreviations: HECV, Human endothelial vascular cell lines; NRU, neutral red uptake.

Values are expressed as viability percentages and represent the mean$\mathrm{S} \pm \mathrm{SEM}$ of 4 separate experiments run in triplicate.

${ }^{*} P<0.05$ vs untreated cells; ${ }^{\circ} P<0.05$ vs $\mathrm{FeSO}_{4} /$ ascorbate-treated cells in absence of timolol.

panel). As reported by Camoirano et $a l^{31}$ the chemopreventive efficacy of timolol in counteracting oxidative damage was calculated according to the formula $\mathrm{A}-\mathrm{B} / \mathrm{C}-\mathrm{D} \times 100$, were $\mathrm{A}, \mathrm{B}, \mathrm{C}$, and $D$ are 8 -oxo$\mathrm{dG}$ levels in $\mathrm{Fe} /$ Asc-treated $(A)$, untreated $(B)$, timolol $+\mathrm{Fe} /$ Asc-treated $(C)$, and timolol-only treated
Table 2 Effects of pretreatment of HECV cells with timolol on the levels of TBARS resulting from iron/ascorbate-induced lipid peroxidation

\begin{tabular}{lcc}
\hline Pretreatment & $\begin{array}{c}\text { Pro-oxidant } \\
\text { None }\end{array}$ & $\mathrm{FeSO}_{4} /$ ascorbate \\
\hline None & $56 \pm 2.5$ & $170 \pm 13.4^{*}$ \\
Timolol & $60 \pm 3.2$ & $80 \pm 9.1^{\circ}$ \\
\hline
\end{tabular}

Abbreviations: HECV, human endothelial vascular cell lines; TBARS, thiobarbituric acid reactive substances.

Results are expressed as pmol of TBARS equivalents $/ 10^{5}$ cells. Data are means \pm SEM of three separate experiments, run in triplicate.

${ }^{*} P<0.01$ vs untreated cells; ${ }^{\circ} \mathrm{P}<0.05$ vs $\mathrm{FeSO}_{4} /$ ascorbate-treated cells in absence of timolol.

(D) cells. Accordingly, timolol was demonstrated to inhibit $95.6 \%$ of the $\mathrm{Fe} /$ Asc-induced oxidative damage. However, the 8-oxo-dG increase induced by $\mathrm{Fe}$ / Asc also in the case of timolol pretreatment was still significantly higher than those detected both in timolol-only-treated cells $(1.96 \pm 0.39$ vs $0.55 \pm 0.12, P<0.01)$ and in untreated cells $(1.96 \pm 0.39$ vs $0.51 \pm 0.10, P<0.01)$ (Table 3$)$. 


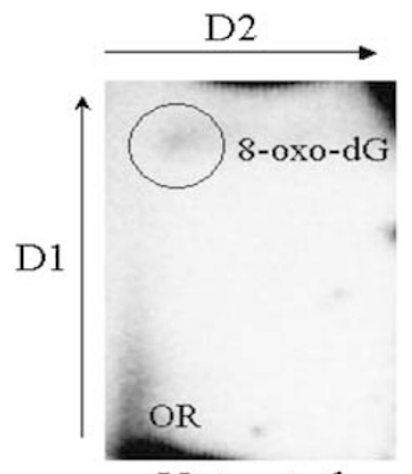

Untreated

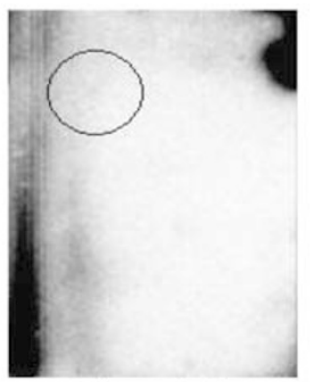

Timolol

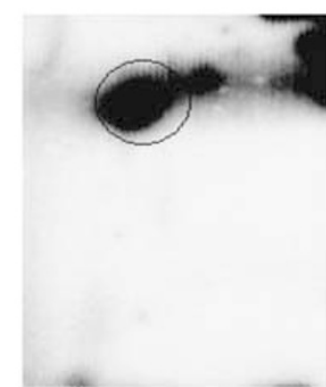

$\mathrm{Fe} / \mathrm{Asc}$

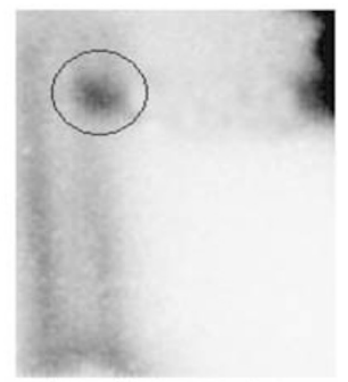

Timolol $+\mathrm{Fe} / \mathrm{Asc}$
Figure 2 Detection of 8-hydroxy-2'-deoxyguanosine (8-oxo-dG) by ${ }^{32} \mathrm{P}$-postlabelling and bi-directional thin-layer chromatography in variously treated HECV cells. The origin (OR) of the chromatography is located at the lower left corner. D1 development was performed in $1.5 \mathrm{M}$ formic acid, $\mathrm{pH} 1.5$, from bottom to top. D2 development was performed in $0.6 \mathrm{M}$ ammonium formate, $\mathrm{pH}$ 6.0, from left to right.

Table 3 Effects of pretreatments of HECV cells with timolol on oxidative DNA damage (8-oxo-dG) resulting from iron/ascorbate oxidative stress

\begin{tabular}{lcc}
\hline Pretreatment & $\begin{array}{c}\text { Pro-oxidant } \\
\text { None }\end{array}$ & FeSO $_{4} /$ ascorbate \\
\hline None & $0.51 \pm 0.10$ & $32.65 \pm 4.58^{* * *}$ \\
Timolol & $0.55 \pm 0.12$ & $1.96 \pm 0.39^{* * \circ \circ 00}$ \\
\hline
\end{tabular}

Abbreviations: HECV, human endothelial vascular cell lines.

Results are expressed as 8-oxo-dG molecules $/ 10^{5}$ normal nucleotides. Data are means \pm SD of three separate experiments.

${ }^{* *} P<0.01$ and ${ }^{* * *} P<0.001$ vs untreated cultures; ${ }^{\circ 00} P<0.001$ vs $\mathrm{FeSO}_{4} /$ ascorbate-treated cells in absence of timolol.

\section{Discussion}

Timolol maleate is widely used as a topical $\beta$-adrenergic blocking agent to lower IOP in glaucoma patients. ${ }^{32}$ This drug decreases diurnal IOP by reducing the aqueous humour flow, ${ }^{33}$ whose rate at night is about half of daytime values. ${ }^{34}$ Accordingly, topical timolol has little effect on night time aqueous humour outflow, ${ }^{35}$ whereas twice per day administrations of timolol significantly decreased IOP at night, albeit to a lesser degree than during the day. ${ }^{36}$ This finding suggests that timolol displays a different mechanism in decreasing IOP in diurnal and in nocturnal periods.

Despite being used for many years, the precise mechanism of action of timolol on aqueous humour is not yet fully understood. ${ }^{37}$ In clinical studies, timolol has been shown to have preservative actions in glaucoma, hampering the progression of visual field damage, opticnerve disc cupping, and decreased retinal thickness. ${ }^{38,39}$ These results suggest that timolol, in addition to being an ocular-hypotensive drug, also exerts neuroprotective effects against neuronal damage. It has been demonstrated that timolol displays a direct neuroprotective effect in experimental models of retinal injury and these protective effects are due in part to a mechanism independent of its action as an ocular hypotensive agent. ${ }^{40}$ Some authors deny the neuroprotective effect of timolol; ${ }^{41}$ nevertheless, recent studies support a potential neuroprotective effect of $\beta$ blockers ${ }^{40,42}$ although to a lesser extent than other molecules ${ }^{43}$ thus suggesting that the neuroprotective effect of timolol is possible, although in some way controversial.

It has been proposed that timolol acts as a $\beta$-adrenergic antagonist displaying a vasodilating activity mediated by nitric oxide. ${ }^{41}$ The trabecular meshwork has been shown to be composed of contractile elements, which regulate the outflow facility. ${ }^{44}$ HTM is a complex dynamic organ responding to vasoactive substances, including vasoconstrictors, such as endothelins, and vasodilators, such as nitric oxide(NO). A balance between vasoconstrictors and vasodilators is necessary for the maintenance of the physiological structure and function of endothelia. ${ }^{45}$ Whenever the balance between vasoconstriction and vasodilatation is disrupted, as in glaucoma, the outcome is endothelial dysfunction and injury, triggering the glaucomatous pathogenic cascade. ${ }^{46}$

The possibility that timolol excites vasodilatation through NO production is questionable. It has been demonstrated in an experimental rat model of elevated intraocular pressure that high NO levels, synthesized by the NOS- 1 and -2 isoforms, contribute to the progressive lesions of retinal ganglion cell axons; NO reduction after treatment with timolol, therefore, suggests a possible neuroprotective effect of timolol in neurons exposed to excessive amounts of NO. ${ }^{42}$ Conversely, NOS-2 synthesis in glaucomatous optic neuropathy is not associated with a significant change in the expression of NOS-2 in the retina or optic nerve. ${ }^{47}$ Accordingly, it can be proposed that timolol is devoid of vasodilating effect in the retinal and in posterior ciliary arteries, although a similar activity in other ocular compartments cannot be excluded. This is because our experimental approach 
focuses on endothelial cells represented by the widely used HECV cell line well standardized in its experimental applications, endothelial cells representing pivotal elements of a variety of ocular tissues including vessel, iris, and cornea.

A possible further mechanism of action of timolol is its activity on NMDA receptors. ${ }^{48,49}$ It has been reported that reducing agents upregulate NMDA receptor activity, while oxidizing agents downregulate it by forming disulfide bonds. By acting as an oxidant, NO may cause S-nitrosylation of NMDA receptor, downregulating the receptor activity.

We also hypothesize that endothelial cells represent an important target for timolol, which could widen the trabecular meshwork endothelial surface, thus increasing the number of cells exposed to the aqueous humour, and thereby favouring endothelial aqueous humour drainage towards the Schelemm's canal.

The purpose of the present study was to investigate directly in cultured endothelial cells the antioxidant capacity of timolol and to clarify whether or not this drug displays any toxic effects on endothelial cells. Under our experimental conditions, timolol was demonstrated to act as an antioxidant, counteracting cytotoxic, and oxidative effects of the Fe/Asc mixture without displaying per se toxic or oxidative effect.

The antioxidant activity of timolol is likely to be related to its metabolism involving the oxidation and hydrolytic cleavage of its morpholine ring, which can be a target for reactive oxygen species.

The lack of adverse effect is in line with in vivo studies in pigs reporting that timolol does not affect the optic nerve oxygen tension despite its lowering effect on IOP. ${ }^{50}$ The antioxidant activity of timolol was reported previously in vitro in neutrophils, demonstrating direct radical scavenging, inhibition of protein kinase $C$, and neutrophil chemotaxis. ${ }^{51}$ In vivo, oxygen induced rethinopathy in newborn rats was inhibited by timolol treatment. $^{52}$

Timolol also displays protective effects against the neuronal damage induced by glutamate in rat retina, ${ }^{40}$ further confirming the antioxidant attitude of timolol because glutamate exerts its cytotoxicity through oxidative damage, as demonstrated in retinal ganglion cells. $^{53}$

The MTT test used under our experimental conditions specifically evaluates mitochondrial function.

Mitochondria are known to be very sensitive to oxidative stress conditions ${ }^{54}$ explaining the reported impairment of mitochondrial functions associated with several pathological states. Our results indicate that mitochondria of endothelial cells are sensitive to oxidative damage and timolol is effective in preventing this alteration.
Many studies highlight the role of oxidative damage in the pathogenesis of degenerative POAG ${ }^{1,55-57}$ and its capacity of damaging not only HTM but also the optic nerve head. ${ }^{58}$ HTMs of glaucoma-bearing patients display increased level of oxidative damage as compared to those of unaffected subjects, ${ }^{17}$ resulting in the occurrence of histological and functional alterations, ${ }^{59}$ including cell shrinkage, chromatin condensation, internucleosomal DNA fragmentation, and cell death. Although the exact cause of cell death is still unclear, an important role is likely to be exerted by apoptosis. ${ }^{60}$ It has been also reported that glaucoma patients could be genetically predisposed to an increased occurrence of oxidative damage in HTM because of the deletion of the glutathione S-transferase M1 gene, a pivotal antioxidant activity. ${ }^{17,61-63}$

Our study suggests that the therapeutic effect of timolol towards glaucoma is likely to be, at least in part, related to its antioxidant activities. The results reported herein indicate that also a validated $\beta$-blocker used in glaucoma therapy exerts antioxidant activities able to protect endothelial cells from oxidative damage in the absence of adverse affect on cell function and viability. Baudouin et $a l^{64}$ demonstrated both in experimental model and glaucoma patients that preserved antiglaucoma drugs induce significant inflammatory and histopathologic changes in the ocular surface and in deeper ocular structures. These toxic effects on the ocular surface, can be in part explained by the presence of benzalkonium chloride, ${ }^{65}$ an agent able to induce apoptosis in conjunctival cells as a consequence of reactive oxygen species production. ${ }^{66}$ Accordingly, unpreserved timolol displays less toxicity than preserved $\beta$-blockers towards human fibroblasts culture. ${ }^{67,68}$ In our study, we used unpreserved timolol, which resulted to be devoid of toxicity towards endothelial cells.

Our study, in agreement with Gomes and coworkers, ${ }^{69}$ was opposed to Melena and Osborne research, ${ }^{70}$ in which timolol was not found to reduce significantly iron/ascorbate-induced lipid peroxidation in rat brain homogenates.

However, the experimental conditions we adopted do not provide a direct evidence that this protective mechanism is exerted in vivo in glaucoma patients. Even if being active on these endothelial cells this $\beta$-adrenergic antagonist used topically could act on the AC like a vasodilator. Therefore, similar to other vasodilators, it could increase the intertrabecular meshwork spaces (exposing other cells to the AC humour), protect the endothelial cells (with antioxidant mechanism) and diminish the pressure of the AC lumen (diminishing the production of aqueous humour).

Of course, this is an in vitro and not in vivo study using vascular and not HTM endothelial cells. Furthermore, the 
amounts of both oxidative damage and timolol exceed those occurring under in vivo conditions.

Therefore, further studies are needed to demonstrate that timolol displays antioxidant properties in vivo in the anterior chamber of the eye. The study of the possible antioxidant effects of timolol primary culture and more complex ocular structures will be the objective of future studies to be considered after the positive results provided by the presented study. In fact, our results provide evidence that timolol, in addition to be an effective and important agent for the reduction of IOP in glaucoma therapy, displays antioxidant activity, thus also supporting the hypothesis that the production of reactive oxygen species represents an important pathogenic element of the glaucoma cascade.

\section{References}

1 Moreno MC, Campanelli J, Sande P, Sanez DA, Keller Sarmiento MI, Rosenstein RE. Retinal oxidative stress induced by high intraocular pressure. Free Rad Biol Med 2004; 37: 803-812.

2 The Advanced Glaucoma Intervention Study (AGIS): 7. The relationship between control of intraocular pressure and visual field deterioration. Am J Ophthalmol 2000; 130: 429-440.

3 Collaborative Normal-Tension Glaucoma Study Group (CNTGSG). Comparison of glaucomatous progression between untreated patients with normal-tension glaucoma and patients with therapeutically reduced intraocular pressures. Am J Ophthalmol 1998; 126: 487-497.

4 Prasanna G, Hulet C, Desai D, Krishnamoorthy RR, Narayan S, Brun AM et al. Effect of elevated intraocular pressure on endothelin-1 in a rat model of glaucoma. Pharmacol Res 2005; 51: 41-50.

5 Knepper PA, Goossens W, Palmberg PF. Glycosaminoglycan stratification of the juxtacanalicular tissue in normal and primary open-angle glaucoma. Invest Ophthalmol Vis Sci 1996; 37: 2414-2425.

6 Lutjen-Drecoll E, Rohen JW. Morphology of aqueous outflow pathways in normal and glaucomatous eyes. In: Ritch R, Shields MB, Krupin T, (eds). The Glaucomas, 2nd ed Vol 1 Mosby: St. Louis, 1996; 89-123.

7 Brandt JD, O'Donnell ME. How does the trabecular meshwork regulate outflow? Clues from the vascular endothelium. J Glaucoma 1999; 8: 328-339.

8 Ferreira SM, Lerner SF, Brunzini R, Evelson PA, Llesuy SF. Oxidative stress markers in aqueous humor of glaucoma patients. Am J Ophthalmol 2004; 137: 62-69.

9 Wang N, Chintala SK, Fini ME, Schuman JS. Activation of a tissue-specific stress response in the aqueous outflow pathway of the eye defines the glaucoma disease phenotype. Nat Med 2001; 7: 304-309.

10 Alvarado JA, Alvarado RG, Yeh RF, Franse-Carman L, Marcellino GR, Brownstein MJ. A new insight into the cellular regulation of aqueous outflow: how trabecular meshwork endothelial cells drive a mechanism that regulates the permeability of Schlemm's canal endothelial cells. Br J Ophthalmol 2005; 89: 1500-1505.
11 Sit AJ, Coloma FM, Ethier CR, Johnson M. Factors affecting the pores of the inner wall endothelium of Schlemm's canal. Invest Ophthalmol Vis Sci 1997; 38: 1517-1525.

12 Johnstone MA. The aqueous outflow system as a mechanical pump: evidence from examination of tissue and aqueous movement in human and non-human primates. J Glaucoma 2004; 13: 421-438.

13 Alvarado JA, Murphy C Juster R. Trabecular meshwork cellularity in primary open-angle glaucoma and nonglaucomatous normals. Ophthalmology 1984; 91: 564-579.

14 Liton PB, Challa P, Stinnett S, Luna C, Epstein DL, Gonzalez $P$. Cellular senescence in the glaucomatous outflow pathway. Exp Gerontol 2005; 40: 745-748.

15 Campisi J. Senescent cells, tumor suppression, and organismal aging: good citizens, bad neighbors. Cell 2005; 120: $513-522$

16 Spector A, Ma W, Wang RR. The aqueous humor is capable of generating and degrading $\mathrm{H} 2 \mathrm{O} 2$. Invest Ophthalmol Vis Sci 1998; 39: 1188-1197.

17 Izzotti A, Sacca SC, Cartiglia C, De Flora S. Oxidative deoxyribonucleic acid damage in the eyes of glaucoma patients. Am J Med 2003a; 114: 638-646.

18 Flammer J. The vascular concept of glaucoma. Surv Ophthalmol 1994; 38: 3-6.

19 Wang X, Desai K, Chang T, Wu L. Vascular methylglyoxal metabolism and the development of hypertension. J Hypertens 2005; 23(8): 1565-1573.

20 Borenfreund E, Puerner JA. Toxicity determined in vitro by morphological alterations and neutral red absorbtion. Toxicol Lett 1985; 24: 119-124.

21 Riddel RJ, Clothier RH, Balls M. An evaluation of three in vitro cytotoxicity assays. Food Chem Toxicol 1986; 24: 469-471.

22 Mosmann T. Rapid colorimetric assay for cellular growth and survival: application to proliferation and cytotoxicity assays. J Immunol Meth 1983; 65: 55-63.

23 Cheeseman KH, Beavis A, Esterbauer H. Hydroxyl-radicalinduced iron-catalysed degradation of 2-deoxyribose. Quantitative determination of malondialdehyde. Biochem J 1988; 252: 649-653.

24 Draper HH, Hadley M. A review of recent studies on the metabolism of exogenous and endogenous malondialdehyde. Xenobiotica 1990; 20: 901-907.

25 Iguchi H, Kojo S, Ikeda M, Masayuki I. Lipid peroxidation and disintegration of the cell membrane structure in cultures of rat lung fibroblasts treated with asbestos. J Appl Toxicol 1993; 13: 269-275.

26 Bassi AM, Ledda S, Penco S, Menini S, Muzio G, Canuto RA et al. Changes of CYP 1A1, GST and ALDH 3 enzymes in hepatoma cell lines undergoing enhanced lipid peroxidation. Free Rad Biol Med 2000; 29: 1186-1196.

27 Bassi AM, Ledda S, Valentini S, De Pascale MC, Rossi S, Odetti $\mathrm{P}$ et al. Damaging effects of advanced glycation endproducts in the murine macrophage cell line J774A.1. Toxicol In Vitro 2002; 16: 339-347.

28 Ames BN, Gold LS. Endogenous mutagens and the causes of aging and cancer. Mutat Res 1991; 250: 3-16.

29 Izzotti A, Cartiglia C, Saccà S, De Flora S. Methodology for evaluating oxidative DNA damage and metabolic genotypes in human trabecular meshwork. Toxicol Meth 2003; 13: 161-168.

30 Izzotti A, Cartiglia C, Tanningher M, De Flora S, Balansky R. Age-related increases of 8-hydroxy-2'-deoxyguanosine and DNA protein cross-link in rat organs. Mutat Res 1999; 446: 215-223. 
31 Camoirano A, Balansky RM, Bennicelli C, Izzotti A, D'Agostini F, De Flora S. Experimental databases on inhibition of the bacterial mutagenicity of 4-nitroquinoline 1-oxide and cigarette smoke. Mutat Res 1994; 317: 89-109.

32 Zimmerman TJ. Topical ophthalmic beta blockers: a comparative review. J Ocul Pharmacol 1993; 9: 373-384.

33 Coakes RL, Brubaker RF. The mechanism of timolol in lowering intraocular pressure. Arch Ophthalmol 1978; 96: 2045-2048.

34 Reiss GR, Lee DA, Topper JE, Brubaker RF. Aqueous humor flow during sleep. Invest Ophthalmol Vis Sci 1984; 25 776-778.

35 Topper JE, Brubaker RF. Effects of timolol, epinephrine, and acetazolamide on aqueous flow during sleep. Invest Ophthalmol Vis Sci 1985; 26: 1315-1319.

36 Konstas AGP, Maltezos AC, Gandi S, Hudgins AC, Stewart WC. Comparison of 24-hour intraocular pressure reduction with two dosing regimens of latanoprost and timolol maleate in patients with primary open-angle glaucoma. Am J Ophthalmol 1999; 128: 15-20.

37 Kiland JA, Gabelt BT, Kaufman PL. Studies on the mechanism of action of timolol and on the effects of suppression and redirection of aqueous flow on outflow facility. Exp Eye Res 2004; 78: 639-651.

38 Schwartz B, Lavin P, Takamoto T, Araujo DF, Smits G. Decrease of optic disc cupping and pallor of ocular hypertensives with timolol therapy. Acta Ophthalmol Scand 1995; 215: 5-21.

39 Vogel R, Crick RP, Mills KB, Reynolds PM, Sass W, Clineschmidt CM et al. Effect of timolol versus pilocarpine on visual field progression in patients with primary open-angle glaucoma. Ophthalmology 1992; 99: 1505-1511.

40 Goto W, Ota T, Morikawa N, Otori Y, Hara H, Kawazu K et al. Protective effects of timolol against the neuronal damage induced by glutamate and ischemia in the rat retina. Brain Res 2002; 958: 10-19.

41 Gross RL, Hensley SH, Gao F, Wu SM. Retinal ganglion cell dysfunction induced by hypoxia and glutamate: potential neuroprotective effects of beta-blockers. Surv Ophthalmol 1999; 43: S162-70.

42 Vidal L, Diaz F, Villena A et al. Nitric oxide synthase in retina and optic nerve head of rat with increased intraocular pressure and effect of timolol. Brain Res Bull 2006; 70: 406-413.

43 Zhang J, Wu SM, Gross RL. Effects of beta-adrenergic blockers on glutamate-induced calcium signals in adult mouse retinal ganglion cells. Brain Res 2003; 959: 111-119.

44 Zanchetti A. Clinical pharmacodynamics of nebivolol: new evidence of nitric oxide-mediated vasodilating activity and peculiar haemodynamic properties in hypertensive patients. Blood Press Suppl 2004; 1: 17-32.

45 Wiederholt $M$, Thieme H, Stumpff F. The regulation of trabecular meshwork and ciliary muscle contractility. Prog Retin Eye Res 2000; 19: 271-295.

46 Gibbons GH. Endothelial function as a determinant of vascular structure and function: a new therapeutic target. Am J Cardiol 1997; 79: 3-8.

47 Pang IH, Johnson EC, Jia L, Cepurna WO et al. Evaluation of Inducible Nitric Oxide Synthase in Glaucomatous Optic Neuropathy and Pressure-Induced Optic Nerve Damage. Invest Ophthalmol Vis Sci 2005; 46: 1313-1321.

48 Lipton SA, Choi YB, Pan ZH et al. A redox based mechanism for the neuroprotective and neurodestructive effects of nitric oxide and related nitroso-compounds. Nature 1993; 364: 626-632.

49 Smythies J. Redox mechanisms at the glutamate synapse and their significance: a review. Eur J Pharmacol 1999; 370: $1-7$.

50 Kiilgaard JF, Pedersen DB, Eysteinsson T, La Cour M, Bang K, Jensen PK et al. Optic nerve oxygen tension: the effects of timolol and dorzolamide. Br J Ophthalmol 2004; 88: 276-279.

51 Djanani A, Kaneider NC, Meierhofer C, Sturn D, Dunzendorfer S, Allmeier $\mathrm{H}$ et al. Inhibition of neutrophil migration and oxygen free radical release by metipranolol and timolol. Pharmacology 2003; 68: 198-203.

52 Ricci B, Minicucci G, Manfredi A, Santo A. Oxygen-induced retinopathy in the newborn rat: effects of hyperbarism and topical administration of timolol maleate. Graefes Arch Clin Exp Ophthalmol 1995; 233: 226-230.

53 Aoun P, Simpkins JW, Agarwal N. Role of PPAR-gamma ligands in neuroprotection against glutamate-induced cytotoxicity in retinal ganglion cells. Invest Ophthlmol Vis Sci 2003; 44: 2999-3004.

54 Castilho RF, Meinicke AR, Almeida AM, Hermes-Lima A, Vercesi AE. Oxidative damage of mitochondria induced by $\mathrm{Fe}(\mathrm{II})$ citrate is potentiated by $\mathrm{Ca}$ and includes lipid peroxidation and alterations in membrane proteins. Arch Biochem Biophys 1994; 308: 158-163.

55 Ferreira SM, Lerner SF, Brunzini R, Evelson PA, Llesuy SF. Oxidative stress markers in aqueous humor of glaucoma patients. Am J Ophthalmol 2004; 137: 62-69.

56 Takahashi A, Masuda A, Sun M, Centonze VE, Herman B. Oxidative stress-induced apoptosis is associated with alterations in mitochondrial caspase activity and Bcl-2-dependent alterations in mitochondrial $\mathrm{pH}(\mathrm{pHm})$. Brain Res Bull 2004; 62: 497-504.

57 Izzotti A, Bagnis A, Saccà S. The role of oxidative stress in glaucoma. Mutat Res 2006; 612: 105-114.

58 Saccà SC, Pascotto A, Camicione $\mathrm{P}$, Capris $\mathrm{P}$, lzzotti A. Oxidative DNA damage in the human trabecular meshwork: clinical correlation in patients with primary open-angle glaucoma. Arch Ophthalmol 2005; 123: 458-463.

59 Zhou L, Li Y, Yue BY. Oxidative stress affects cytoskeletal structure and cellmatrix interactions in cells from an ocular tissue: the trabecular meshwork. J Cell Physiol 1999; 180: 182-189.

60 Wyllie AH, Kerr JF, Currie AR. Cell death: the significance of apoptosis. Int Rev Cytol 1980; 68: 251-306.

61 Juronen E Tasa G, Veromann S Parts L, Tiidla A, Pulges R, Panov A, Soovere L et al. Polymorphic GSTM1 is a risk factor of POAG. Exp Eye Res 2000; 71: 447-452.

62 Izzotti $\mathrm{A}$, Saccà S. Glutathione S-transferase M1 and its implication in glaucoma pahogenesis: a controversial matter. Exp Eye Res 2004; 79: 141-142.

63 Yildirim O, Ates NA, Tamer L, Oz O, Yilmaz A Atik U, Camadeviren H. May glutathione S-transferase M1 positivie genotype afford protection against primary open angle glaucoma? Graefes Arch Clin Exp Ophthalmol 2005; 243: 327-333.

64 Baudouin C, Pisella PJ, Goldschild M, Becquet F, De Saint Jean M, Bechetoille A. Ocular surface inflammatory changes induced by topical antiglaucoma drugs: human and animal studies. Ophthalmology 1999; 105: 556-563.

65 Young TL, Higginbotham EJ, Zou X, Farber MD. Effects of topical glaucoma drugs on fistulized rabbit conjunctiva. Ophthalmology 1990; 97: 1423-1427. 
66 De Saint Jean M, Brignole F, Bringuier AF, Bauchet A, Feldmann G, Baudouin C. Effects of benzalkonium chloride on growth and survival of Chang conjunctival cells. Invest Ophthalmol Vis Sci 1999; 40: 619-630.

67 Debbasch C, Brignole F, Pisella PJ, Warnet J-M, Rat P, Baudouin C. Preservatives' contribution in oxidative stress and apoptosis on Chang conjunctival cells. Invest Ophthalmol Vis Sci 2001; 42: 642-652.

68 Debbasch C, Pisella PJ, De Saint Jean M, Rat P, Warnet JM, Baudouin C. Mitochondrial activity and glutathione injury in apoptosis induced by unpreserved and preserved betablockers on Chang conjunctival cells. Invest Ophthalmol Vis Sci 2001; 42: 2525-2533.

69 Gomes A, Costa D, Lima JL, Fernandes E. Antioxidant activity of beta-blockers: an effect mediated by scavenging reactive oxygen and nitrogen species? Bioorg Med Chem 2006; 14: 4568-4577.

70 Melena J, Osborne N. Metipranolol attenuates lipid peroxidation in rat brain: a comparative study with other antiglaucoma drugs. Graefe's Arch Clin Exp Ophthalmol 2003; 241: 827-833. 